\section{Public goods and government action}

Politics, Philosophy \& Economics 2015, Vol. 14(2) 109-128

(C) The Author(s) 2013

Reprints and permissions: sagepub.co.uk/journalsPermissions.nav DOI: I0.I I77/I470594XI35054I4 ppe.sagepub.com

@SAGE

\author{
Jonathan Anomaly \\ Duke University, USA
}

\begin{abstract}
It is widely agreed that one of the core functions of government is to supply public goods that markets either fail to provide or cannot provide efficiently. I will suggest that arguments for government provision of public goods require fundamental moral judgments in addition to the usual economic considerations about the relative efficacy of markets and governments in supplying them. While philosophers and policymakers owe a debt of gratitude to economists for developing the theory of public goods, the link between public goods and public policy cannot be forged without moral reflection on the proper function and scope of government power.
\end{abstract}

\title{
Keywords
}

Public goods, public policy, market efficiency, government intervention, paternalism

\section{Why public goods matter}

Markets are miraculous mechanisms for enhancing human welfare. In the absence of externalities, the free exchange of private goods leads to (presumptive) Pareto improvements. Even when externalities occur, market exchange tends to produce net gains by promoting specialization and the division of labor (Smith, 1776; Bk 1, chs 1-3). But when confronted with public goods like the preservation of our atmosphere's ozone layer, uncoordinated exchange can leave everyone worse off than they might otherwise be if they could find a way to coordinate.

Goods are public if they exhibit nonrivalry and nonexcludability. ${ }^{1}$ Of the two characteristics, nonexcludability arguably poses the main challenge for producing public goods

\section{Corresponding author:}

Jonathan Anomaly, Duke University, I40 Science Drive, Room 208 Gross Hall, Box 90204, Durham, NC 27708, USA.

Email: jonathan.anomaly@duke.edu 
privately. $^{2}$ This is because - in textbook cases — when a good is available to all and is costly to produce, some people will be tempted to free ride on the efforts of others. Other people, recognizing the existence of free riders, will decline to contribute because they lack the assurance that enough others will pitch in to make their effort worthwhile.

As a general rule, when the number of people needed to produce a public good increases, the feasibility of market provision declines and welfare gains are accordingly difficult to produce through private exchange. In other words, public goods pose a problem-for welfare economics, at least - to the extent that they induce market failure. Thus, many have argued, government can potentially improve the situation by directly supplying or indirectly encouraging the provision of public goods.

Indeed, Adam Smith argued that governments should be tasked with three main roles, all of which can be aptly described as the provision of public goods. The first two are to supply a military to defend against external invasion, and to maintain an impartial legal and judicial system. 'The third and last duty of the sovereign or commonwealth,' Smith says,

is that of erecting or maintaining those public institutions and those public works, which, although they may be in the highest degree advantageous to a great society, are, however, of such a nature, that the profit could not repay the expense to any individual or small number of individuals, and which it therefore cannot be expected that any individual or small number of individuals should erect or maintain (1776: Bk 5, ch. 1).

As it turns out, the problem of producing public goods is primarily about how the number of contributors needed to produce them affects transaction costs (Coase, 1960) and strategic behavior (Buchanan, 1999). ${ }^{3}$ When a public good is local, like a neighborhood playground, its potential beneficiaries can usually find a way to coordinate and forge a contract that facilitates private provision. They can also develop mechanisms to exclude free riders and solve the assurance problem through conditionally binding contracts (Schmidtz, 1987). When a public good is global in scope, like the reduction of ozone-depleting chemical emissions, it often becomes more difficult-sometimes impossible - for the relevant parties to find one another, for negotiators to distinguish free riders from honest holdouts, and for private provision to occur.

Economists consider public goods problematic because they represent situations in which free markets can lead to unexploited gains from trade. But they also pose a problem for political philosophy if, following Rawls, we think of political society as a 'cooperative venture for mutual advantage' (Rawls, 1971: 4). Voluntary exchange is a key source of mutual advantage, but when the costs of producing a collective good are borne by individuals, while the benefits are dispersed, mutual gains may require government action. In a sense, coercively enforced government mandates (such as laws regulating pollution) can be considered a kind of cooperation for mutual advantage if each person whose liberty is limited sees this as the only feasible way to achieve a goal that makes everyone better off. The question for political philosophy, then, is how we should think about the vast range of public goods that markets and governments might provide.

My concern in this article is to develop the rudiments of a normative theory of public goods. I'll begin with a brief discussion of why many philosophers think public goods provision should form the core of government action, and then develop a set of questions 
that theorists and policy makers should ask when confronted with prospective public goods. The objective is not to provide definitive answers to these questions, but rather to frame the issue without settling it in favor of any particular view about the proper scope of government action.

\section{Forerunners}

In different ways, Thomas Hobbes and David Hume anticipated Adam Smith's view that the fundamental function of government is to provide public goods. Hobbes argued that the creation and enforcement of rules of conduct, including moral and legal rules, allow us to rise above the state of nature and enjoy the fruits of our labor: without enforceable laws, unrestrained competition for scarce resources threatens our security and undermines our ability to trust people with whom we would otherwise interact. In a state of nature, Hobbes tells us:

... there is no place for industry, because the fruit thereof is uncertain: and consequently no culture of the earth; no navigation, nor use of the commodities that may be imported by sea; no commodious building; no instruments of moving and removing such things as require much force; no knowledge of the face of the earth; no account of time; no arts; no letters; no society; and which is worst of all, continual fear, and danger of violent death... (1651: Bk 1, ch. 13).

The only way to avoid this disaster, Hobbes thinks, is for people 'to confer all their power and strength upon one man, or upon one assembly of men, that may reduce all their wills, by plurality of voices, unto one will' (1651: Bk 1, ch. 17). As many commentators have suggested (Hampton, 1986; Kavka, 1986) Hobbes's argument for despotism is less interesting than his argument that life in a political society typically makes all of us better off than we would be in a state of nature, and thus that government itself is a public good, as well as a potential supplier of public goods. Eighty years after Hobbes published Leviathan and 200 years before Paul Samuelson coined the term 'public good' (Samuelson, 1954), Hume clearly anticipated the public-goods argument for government action:

Two neighbours may agree to drain a meadow, which they possess in common; because it is easy for them to know each others mind; and each must perceive, that the immediate consequence of his failing in his part, is, the abandoning the whole project. But it is very difficult, and indeed impossible, that a thousand persons should agree in any such action; it being difficult for them to concert so complicated a design, and still more difficult for them to execute it; while each seeks a pretext to free himself of the trouble and expence, and would lay the whole burden on others. Political society easily remedies both these inconveniences. Magistrates find an immediate interest in the interest of any considerable part of their subjects. They need consult no body but themselves to form any scheme for the promoting of that interest. And as the failure of any one piece in the execution is connected, though not immediately, with the failure of the whole, they prevent that failure, because they find no interest in it, either immediate or remote. Thus bridges are built; harbours opened; ramparts raised; canals formed; fleets equipped; and armies disciplined every where, by the care of government, which, though composed of men subject to all human infirmities, becomes, by one of the 
finest and most subtle inventions imaginable, a composition, which is, in some measure, exempted from all these infirmities (Hume, 1739: Bk 3, Pt 2, ch. 7).

In the purest cases-like those mentioned by Hobbes, Hume, and Smith-governments can provide benefits that would be difficult or impossible to attain if individuals were left to their own devices. For this reason, nearly all plausible political theories endorse some government provision of public goods, though each will support a different bundle, and for different reasons. ${ }^{4}$ According to David Schmidtz, 'one of the most attractive features of the public goods argument [for government intervention] is the minimal nature of the normative assumptions it must make in order to ground a justification of the state' (1991: 82). The minimal normative assumption Schmidtz has in mind is that government action is occasionally the only feasible or cost-effective way of bringing about an outcome which each person sees as beneficial—or would see as beneficial under idealized epistemic conditions - but which they lack the power to bring about unilaterally.

One problem with goods that are accessible to a large number of people is that there will usually be some people who consider the good harmful rather than beneficial. After all, a 'good' in the economic sense is any product that can be used to satisfy a desire, not a product that is desirable, or even widely desired. ${ }^{5}$ For example, a public park is a local public good that is considered beneficial by those who use it and those who enjoy seeing trees in their neighborhood. But for those who suffer pollen allergies, or who prefer urban to rural landscapes, parks are a nuisance. When this is true, government provision of public goods begins to look more like redistribution than mutual benefit. ${ }^{6}$

Still, most political philosophers will agree that providing relatively pure public goods should be government's core function. The problem is how to determine which public goods governments should supply.

\section{Public goods and public policy}

When confronted with policies that produce public goods, we should consider the following questions:

1. What is current demand for the good?

2. What would demand be if people had reasonably stable and well-formed preferences?

3. Do the benefits of providing the good exceed the costs of provision?

4. Are the costs and benefits of provision fairly distributed?

5. Would the good be more efficiently provided by government or markets?

6. If a public good is an artifact of public policy, should governments supply it anyway, or should they alter the policies or incentive structures that make the good public to begin with?

7. Is government provision of public goods paternalistic, or otherwise morally objectionable?

In each of the following subsections I will attempt to show why these questions matter, and how difficult it is to answer them. 


\section{Gauging demand}

One problem with deciding which public goods governments should supply is that there is no obvious way of measuring demand. In ordinary markets, goods are produced and sold in discrete units, and firms competing for customers have a powerful incentive to figure out how much of a given good to produce. But public goods cannot be packaged and sold in an obvious way, since suppliers can't attach prices to units of an indivisible good. For example, some people value saving an endangered species or eradicating a disease. But these are not goods that are easy to sell in a market, or to quantify the value of, especially because most of the benefits will go to future people who do not yet exist.

Contingent valuation (CV) surveys try to gauge demand for public goods by asking people how much they would be willing to pay for the production or preservation of public goods. CV surveys seem like a scientifically sound and morally neutral way of using hypothetical markets to calculate how much people want a good that actual markets are unlikely to produce. But CV surveys suffer serious problems, and it is unclear whether they are capable of accurately revealing demand for public goods.

A familiar problem with contingent valuation stems from biases embedded in survey questions and in the psychology of survey subjects. For example, in surveys with lists of different public goods, people's willingness to pay seems to vary greatly with the ordering of items on the list (Samples and Hollyer, 1990; Tolley et al., 1983). When people are asked how much they would pay to save an endangered elephant, say, or to clean up a polluted lake, their answer is partly determined by which question is posed first. In one survey, respondents were asked how much they would pay to preserve each of three different wilderness areas, and then asked how much they would be willing to pay to preserve all three. In some cases, people were willing to pay more to preserve each of three wilderness areas than they would to preserve all three together (Diamond et al., 1993).

In addition to $\mathrm{CV}$ surveys eliciting apparently inconsistent responses, some researchers question whether survey subjects are attempting to state their true demand for public goods. The worry is not that survey takers will strategically disguise their preferences (since little can be gained by giving false answers to questions about nonbinding projects), but rather that they may be doing something else altogether. For example, Diamond and Hausman (1994) suggest that respondents may be expressing an attitude that gives them a warm glow, even if they wouldn't be willing to support their response to a hypothetical question with actual money; or they may be describing what they think good citizens are supposed to say, rather than calculating how much benefit they would derive, all things considered, from allocating a specific amount to a particular public good.

Limited information further complicates the use of CV surveys to gauge demand for public goods. Because information is costly to gather, and even costlier to process and organize, economists emphasize the role of rational ignorance in decision makingespecially in the realm of science and politics (Downs, 1957; Hayek, 1945). Learning how your microwave oven works will not make it work better, but it will mean you have less time to spend on other valuable pursuits. Learning how price controls on agricultural commodities impact consumers will not repay investment, unless you're a farmer, politician, lobbyist, or an unusually concerned and curious citizen. Generalizing this point, 
consumers of public goods will have little incentive or ability to inform themselves about all possible public goods that might be provided or preserved.

In markets for private goods, consumers internalize the benefits and costs of their purchases. If you don't like your new car or the cup of coffee you've purchased, you have an incentive to spend more time comparing alternative brands of cars and coffee, and adjust your behavior accordingly. But if a new kind of pollutant is thought by scientists to deplete the earth's ozone layer, to warm the planet, or to threaten the ecosystem of an endangered species, there is little reason for most people to study the issue carefully, since each person's consumption choices have a negligible impact on whether the atmosphere is altered, or another species becomes extinct. This line of reasoning suggests that ignorance by respondents to $\mathrm{CV}$ surveys is not anomalous; it is a predictable fact explained by the incentive structure of public goods problems.

Finally, many argue that since willingness to pay for a public good is constrained by ability to pay, how much of a public good people want changes over time, and depends precariously on budget constraints. Poorer people, for example, are usually willing to pay less for environmental goods than wealthier people. The relationship between ability to pay and willingness to pay is further complicated by the fact that questions on CV surveys are usually hypothetical and answers are non-binding. People's stated willingness to pay may be exaggerated by the fact that in answering hypothetical questions they don't need to pay close attention to how much money they actually have, or expect to make (Cornes and Sandler, 1996: 507; Schmidtz, 2001: 169).

To sum up, when people are asked how much they currently value a public good, like the preservation of the endangered Californian condor, their answers may be affected in different ways by their budget constraints, by the order of the questions asked, by the context in which questions are asked, by how much (or little) they know about the Californian condor and its relationship to its ecosystem, and many other variables. This suggests that CV surveys are flawed tools for gauging demand for public goods. Suppose, however, that we could find a more accurate way of measuring demand. Would this imply that governments should supply public goods when demand is strong? Although this may be a prima facie argument for state provision of public goods, other considerations must be addressed first.

\section{Evaluating demand}

As we have seen, one of the most intractable problems with using surveys to gauge demand for public goods is that many people lack the information or expertise to register preferences over important policy issues. Demand can be based on ill-informed, inconsistent, or otherwise poorly formed preferences. It can also be tainted by irrational (in addition to rationally ignorant) political and economic beliefs (Caplan, 2008; Huemer, 2013). ${ }^{7}$ Ultimately, this is not just a problem with the use of surveys, but one that stems from limited information and the incentives surrounding public goods.

This suggests that even if we could measure demand for public goods with a high degree of accuracy, it may not have normative significance or public policy implications. Some economic theories of welfare imply that we are better off - that our welfare is 
increased - when more of our desires are satisfied. But this is a substantive value claim, and it is clearly false in some cases.

First, some desires are part of an inconsistent set, so the satisfaction of one implies the frustration of another. Consider a drug addict with a desire for another fix of heroin and a desire to be the kind of person who doesn't want heroin. In this case, a first order desire (for drugs) conflicts with a second order desire (to not be an addict), and the second order desire seems to have normative authority. This is not to say that all desires for drugs are irrational, or involve internal conflict, but rather that some desires are rooted in impulses we would prefer not to have. It is hard to argue that satisfying such desires makes our lives go better.

Second, some of our desires are based on poorly formed or unjustified beliefs. Consider a recent example. In the early 21 st century, many people in the US and UK declined to vaccinate their children because they believed the measles, mumps and rubella (MMR) vaccine causes autism. The belief can be traced in part to skepticism about the efficacy of vaccines in general, but also to a study conducted in the UK that specifically alleged a causal link between the MMR vaccine and autism. The study was never replicated, the sample on which its conclusions were based was far too small to draw statistically significant conclusions, the lead author of the study had numerous conflicts of interest, and eventually the study was retracted by the journal in which it was published - though not before the British media had managed to convince many citizens of the study's soundness. ${ }^{8}$ In the decade that followed, thousands of parents declined to vaccinate their children because they believed in a bogus causal connection between MMR and autism. Some children died as a consequence; many others acted as vectors for preventable diseases. Beliefs about MMR causing autism were clearly unjustified, but to those who held these beliefs, overturning government requirements or incentives for parents to vaccinate their children constituted a public good for which there was significant demand. This is a paradigm case, however, in which we should not encourage government provision of public goods simply because demand is high. ${ }^{9}$

One way of dealing with this problem is to consider which public goods people would be willing to pay for if they had reasonably well-formed preferences. ${ }^{10}$ Instead of using the satisfaction of actual desires as an automatic index of welfare, or using existing demand to determine which public goods governments ought to supply, we should also consider counterfactual desires, suitably informed. Generally speaking, the satisfaction of desires is more likely to increase a person's welfare if desires are consistent, stable, and based on beliefs that survive critical reflection. ${ }^{11}$ Some argue that we should abandon the connection between desire satisfaction and welfare in favor of a more substantive or objective theory of well-being. ${ }^{12}$ But this is a controversial move because it requires an objective account of value about which there is little consensus. Although such theories should be part of the public discussion, we should avoid defending policies by appealing to controversial theories of value.

A theory of welfare that prioritizes higher order and informed desires captures the intuition that not all desires are equally worth satisfying - that satisfying some desires can diminish rather than enhance welfare. But it allows us to avoid contentious appeals to objective value. For our purposes, it also implies that policy makers should consider providing public goods for which there is widespread demand only if demand is rooted in minimally well-formed preferences. ${ }^{13}$ 


\section{Benefits and costs}

Suppose we agree that policy makers should focus their attention on public goods for which there is (or would be) widespread demand among reasonably reflective and informed citizens. Before concluding that public goods ought to be publicly supplied, we should also consider the magnitude of the costs and benefits associated with government provision.

For example, basic science research is one of the most important public goods human beings can produce, but discoveries about the basic structure of the universe are not patentable. Markets, therefore, may provide a relatively low level of basic science research. ${ }^{14}$ Of course, some people will study science simply to satisfy their curiosity (Galileo and Einstein made many important discoveries in their spare time), and private firms may have some reason to fund basic science research in the hope that it will eventually reward investment. But most firms are run by people whose security and salary depend on short-term profitability rather than the long-term financial health of the firm they work for. And most people have little time to pursue science as a hobby after a long day at work. So there is good reason to believe that individual people and profit-seeking firms will produce less basic science research than they would under a system in which public funding for such research is available. ${ }^{15} \mathrm{Up}$ to a point, the benefits produced by publicly funded basic science research almost certainly exceed the cost of provision, as long as the funds find their way to capable scientists. But how much funding for public goods like basic science research should governments supply?

Welfare economists suggest that governments should attempt to supply an 'efficient' level of public goods. The efficiency criterion is a consequentialist moral standard which I will discuss in a little more detail in the next section. But it is worth emphasizing that requiring government agencies to perform a cost-benefit analysis (CBA) before providing public goods does not commit us to the efficiency criterion of welfare economics, or to any other consequentialist moral theory (Schmidtz, 2001). Instead, tallying up costs and benefits can help us evaluate whether a particular political intervention is justified by highlighting the values at stake, as well as the welfare effects on the relevant parties. CBA can - in principle, at least — help policy makers think through complex issues, and help citizens keep track of how policy makers make decisions.

In the case of basic science research, for instance, we might think about how much money should be spent trying to find out how the influenza virus evolves, and how much (if any) should be allocated to study the chemical composition of Jupiter. If a CBA shows that research into the evolution of flu viruses yields greater returns on investmentreturns that include welfare effects on future people - than research into the composition of planets like Jupiter, policy makers may have reason to prioritize funding for microbiology over planetary astronomy. But this does not imply that we should consider CBA the sole determinant of public goods provision. CBA is bound to be imperfect, and it may fail to capture all of the relevant values at stake (Kelman, 1981), even if it helps policy makers and theorists think through the relevant trade-offs (Schmidtz, 2001). If government provision of a public good fails a CBA, this gives us a strong reason to think government should not provide it. If government provision of a public good passes a CBA, this provides a defeasible reason for the state to provide it. However, we should also 
consider how the benefits and costs of provision are distributed, and whether there are private alternatives to public provision.

\section{Fairness}

Many publicly financed public goods shower benefits on some people and impose costs on others. In some cases, this seems fair: it may be worth spending money now on polio eradication or pollution abatement, even if the primary beneficiaries are future people who don't incur any of the costs. But it is often unfair, as when a US Congressman uses federal tax revenue to finance pet projects in his district in order to curry favor with his constituents. When each Congressman does this, both Congressman and constituents are better off, since the constituents pay only a fraction of the cost of the relevant public good, and the Congressman (who often attaches his name to the road or bridge that is built) is more likely to get re-elected. But when all Congressmen do this, all constituents (though not all Congressmen) are arguably worse off. The overall game is a multi-player prisoner's dilemma, and the aggregate results are evidently unfair.

The subject of distributive justice is a contentious one, and I do not wish to defend any particular view. But it is worth mentioning some prominent distributive principles that policy makers should consider before deciding to use state power to provide public goods. According to the Pareto principle, a public good should be provided if it makes some people better off without leaving others worse off. If the initial starting point is fair, Pareto improvements are among the least controversial distributive moves, even when they require government coercion to produce (Gaus, 2007: ch. 3). Imagine, counterfactually, that everyone considers the current distribution of resources fair, and a proposed program to reduce pollution will cost everyone the equivalent of US\$5 in resources but will benefit everyone by at least US\$5. It looks like this move is both fair and mutually beneficial. The problem is that there are few policies that make some people better off and none worse off.

The Pareto principle, then, appears to be overly restrictive: it prevents states from making almost any policy change, since at least one person is likely to be unhappy with any new policy. One response by proponents of Pareto is to move from the evaluation of specific policies to that of constitutional design (Buchanan and Tullock, 1962; Sugden, 1990). The idea is that if each person must consent to (or be made better off by) any particular policy, no policy change will ever occur. But carefully crafted constitutional rules for policy making could lead to Pareto improvements in the ex ante sense. Not everybody will be happy with any particular policy, but everyone can expect to be better off with whatever set of policies emerges from the decision procedure specified by the constitution. Examples of such constitutional rules include taxing people-to the extent possible-in proportion to the benefit they receive from any particular public good (Buchanan and Brennan, 1999), minimizing the use of taxation as a means of redistribution (Sugden, 1990), and requiring that rules be general, impartial, and universally applicable (Buchanan, 1993).

Whatever general rules constrain the creation of policy, the restrictiveness of the Pareto standard has led many welfare economists and utilitarians to endorse the KaldorHicks principle, according to which the provision of a public good is justified up to the 
point at which net social benefits are maximized, even if this entails a loss for some people. The principle requires that those who gain from a policy can, in principle, compensate the losers. If the losers are compensated, Kaldor-Hicks becomes a more flexible version of the Pareto principle. There are obvious objections to principles that allow policy makers to impose losses on some people so that others may benefit, and my object is not to defend any particular distributive principle.

Instead, I want to emphasize that most real-world public goods do not benefit everyone, and when they do, they do not benefit everyone equally. Even for a pure public good for which there is almost universal demand, such as saving African lions from extinction, there will be some people who consider the outcome deleterious rather than beneficial (tribal people who are occasionally eaten by lions, for example, and people who would rather save elephants, say, than lions). When this is true-when some people bear the costs, and others get the benefits - we should carefully consider whether a public good should be produced at all, who should shoulder the costs, and how it should be produced, given the range of public and private alternatives.

\section{Public and private provision}

Those who write about public goods theory often correctly complain that non-specialists confuse public goods with public policy. People tend to assume that public goods exist whenever government agents attempt to do what is 'good for the public' in some vague sense. This is an understandable mistake. But, in a less excusable mistake, some scholars have accused pioneers of public goods theory of assuming that the failure of markets to provide public goods automatically implies that governments should step in to supply them. For example, Randall Holcombe argues that

public goods theory is part of the government-produced propaganda designed to enhance the appearance of legitimacy of the state...People who believe the theory are more likely to support government intervention into the economy, and are more likely to view government production as a legitimate activity of the state (Holcombe, 2000: 137).

This is a conceptual mistake and a dubious empirical claim.

None of the academic economists who first described public goods made the assumption that the failure of markets to provide public goods always merits government action. In fact, AC Pigou, who is often caricatured as assuming that governments should always correct market failures by taxing negative externalities and subsidizing public goods, warns against this assumption:

It is not sufficient to contrast the imperfect adjustments of unfettered private enterprise with the best adjustment that economists in their studies can imagine. For we cannot expect that any public authority will attain, or will even whole-heartedly seek, that ideal. Such authorities are liable alike to ignorance, to sectional pressure and to personal corruption by private interest (Pigou, 1932: 332). 
Similarly, Samuelson says "the term "public good" ... cannot be interpreted to imply that private goods should be produced by private enterprise and public goods should be produced by government directly'. Instead, Samuelson suggests,

where the consumption externalities intrinsic to a non-private good occur, all that I would insist on is that laissez faire cannot be counted on to lead to an optimum. There is a prima facie case, so to speak, for social concern and scrutiny of the outcome... [But] the exact form in which the social concern ought to manifest itself depends on a host of considerations that have to be added to the model (Samuelson, 1972: 52).

\section{More recently, Hal Varian emphasizes that}

[t]he standard theory of public goods doesn't call for government intervention - it just says that when public goods are present, simple markets won't achieve efficient outcomes. Conventional economic theory is mute on the question of whether there is any other mechanism that will improve upon the market (Varian, 1993: 545). ${ }^{16}$

Indeed, there are two common ways of privately producing public goods: charity and assurance contracts. It is a familiar fact that private charities can produce public goods. For example, the Nature Conservancy buys land from foreign governments and farmers to preserve endangered forests and animals, and Planned Parenthood provides information and contraception services that promote public health by decreasing sexually transmitted diseases and unwanted pregnancies. Most contributors, presumably, have altruistic motivations - they care about improving the lot of other people and animals. But it is also possible to produce public goods for fun or for profit. For example, some people paint murals in public spaces or plant trees in parks in order to beautify a city or restore a native plant habitat. Others produce public goods for less altruistic reasons, including fame, fortune, or necessity. Members of a tribe might pool their labor in order to build a bridge or wage war against their neighbors. Of course, these goods might be described as less than fully public if those who don't contribute are excluded from using the goods, or from other social benefits. In this case people produce collective goods by creating exclusion mechanisms. This suggests that many goods that appear to be public can be transformed into private goods or impure public goods through the invention of subtle exclusion mechanisms. When this is true, there is no reason to assume government is necessary to produce public goods (whether state provision or private provision is more efficient is a separate empirical question).

Another way public goods can be produced privately is that profit-seeking firms may be able to find people who are willing to contribute to a collective endeavor, but who lack the assurance that like-minded people will do their part. Firms can then charge a fee for helping people coordinate their efforts by creating a contract between willing cooperators. It is worth remembering that public goods create two separate problems: the free rider problem (people who want the good, but who try to avoid paying for it), and the assurance problem (people who want a good, and are willing to pay for it, but who fear that others will not contribute enough to produce it). For local public goods that aren't consumed by many people, conditionally binding assurance contracts can solve both 
problems reasonably well (Schmidtz, 1987). Conditionally binding contracts solve the assurance problem by charging people (in money or labor) for a public good only if enough others pledge to contribute to produce the public good. Since most public goods are not binary - they are not all or nothing ${ }^{17}$ — we can imagine a range of such contracts producing different kinds and quantities of public goods. Firms that profit by underwriting such contracts have an incentive to pay careful attention to how much different people are willing to pay for public goods. However, as the number of people needed to produce a public good increases, strategic behavior is likely to emerge, and transaction costs may become prohibitive. This suggests that many large-scale public goods, especially global and inter-generational goods like the reduction of ozone-depleting chemicals, are unlikely to be produced through assurance contracts. Moreover, since contracts must be enforceable to be effective, governments will almost always play some role in the provision of public goods, even if their role is simply to establish the rules of contract and provide judicial arbitration for contract disputes.

The crucial role of government in creating and enforcing the basic rules of the game suggests that the dichotomy between private and public production of public goods is a bit artificial. In addition to enforcing contracts and adjudicating disputes, governments can also facilitate the production of public goods by altering property rights or reducing transaction costs (Coase, 1960; Hampton, 1987). For example, by exempting private charities from taxation, government might facilitate the emergence of public goods without directly producing them (Cowen, 2006). Indeed, this may be preferable in cases where people with local knowledge are better able to determine which public goods would benefit those around them. Still, there is a useful conceptual distinction between government directly producing public goods, and providing them indirectly by creating a legal environment or incentive structure that makes it easier for individuals to do so. For example, to the extent that education creates the public good of skilled citizens and competent voters, governments might produce the good directly through government-run schools, or indirectly by funding a voucher program in which education is competitively produced by privately run schools.

The distinction between direct and indirect provision is especially useful to make when thinking about the efficiency of markets and governments at producing public goods. ${ }^{18}$ As a rule of thumb, markets tend to under-produce public goods, while governments tend to over-produce them. This is true in part because politicians are imperfectly informed, and because they spend other people's money (Schmidtz, 1993; Tullock, 1971). They also have an incentive to deliver gifts to the most politically powerful of their constituents, and impose the costs on less powerful people. Before we conclude that governments should (directly or indirectly) produce public goods, we should keep in mind that state action can create new externalities and novel public goods problems.

\section{Primary and secondary public goods}

When governments produce public goods, they can simultaneously solve old problems and create new ones. For example, in the USA many state governments require citizens to purchase automobile insurance. In theory this is done to pool risk, and to protect people from damage others may impose on them but lack the ability to pay for. ${ }^{19}$ The idea seems to be 
that there is a public good associated with bringing everyone into an insurance pool so that each can share the risks of driving and protect themselves against large losses imposed by those who are both uninsured and cannot afford to pay for the accidents they cause. But a predictable consequence of forced risk-sharing is that people have less incentive to take precautions to protect their own cars from minor accidents and theft. Insurance mandates transform time and money spent on protecting one's car into a public good since all members of the pool bear the cost of damaged property. The only way to encourage people to spend more resources protecting their car is to permit insurance companies to charge copayments, to change the insurance mandate, or to create another policy that encourages each person to take more precaution against theft and damage. Thus, new mandates can both solve and create public goods problems (or, more generally, externalities); they can also impose additional enforcement and compliance costs.

When a public good is an artifact of public policy, it is an open question whether governments should supply it, or whether they should alter the policies that make the good public to begin with. Consider a more controversial example. Many argue that reducing obesity is a public good because it will save money for all people in an insurance pool (in states with private health insurance) or all taxpayers (in states with government-financed health care). Similar arguments are often applied to smokers. Public goods arguments are frequently invoked to justify taxing cigarettes, and regulating what kinds of food and drink people consume. One problem with these arguments is that some evidence indicates that, on average, adults who choose to smoke (or allow themselves to become obese) do not impose net medical costs on other people over their lifetimes, since they die younger but live long enough to contribute nearly as much money in taxes and insurance premiums as healthier people (Barendregt et al., 1997; van Ball et al., 2008). If so, the public goods argument evaporates. However, even if smokers and obese people do impose significant costs on other people, so that there's a public good associated with reducing smoking and obesity, these costs are largely a function of public policy (Anomaly, 2012). This is true partly because insurance companies and other firms are often not allowed to price discriminate by charging more for services rendered to people who engage in risky behavior, and because social welfare programs typically cover people's costs regardless of the choices they make.

When public policy creates new kinds of public goods problems, we should think about whether further policies that attempt to provide the relevant public good should be passed, or whether those that create the problem should be repealed or altered.

\section{Paternalism and self-subversion}

The use of government coercion always raises deep moral questions. ${ }^{20}$ Since compulsion is sometimes the only way for governments to produce some public goods, we should be cautious about how much discretionary power we give to policy makers to decide which public goods should be produced.

I argued above that not all desires are worth satisfying. If demand for public goods stems from poorly formed desires, people will not necessarily be made better off when their desires are satisfied. The converse is also true: people can be made better off when their desires are frustrated. Indeed, many public goods are supplied despite popular 
opposition, and benefit people in ways they fail to understand. Consider free trade agreements, which are mutually beneficial but often unpopular; or treaties that reduce pollution by restricting trade in certain chemicals, such as ozone-depleting chlorofluorocarbons. Few people have an incentive to take economics and environmental science courses, or to inform themselves about the details of international treaties. So it is not surprising that many people are poorly informed about policies that provide global public goods. ${ }^{21}$ When this is true, it may be legitimate for policy makers to provide public goods for which there would be widespread demand if desires were adequately informed.

One of the practical problems with a theory that says some desires count more than others is that it seems to empower policy makers to pass repressive laws by invoking the counterfactual desires their constituents would have if they were more thoughtful or informed. David Schmidtz worries that one problem with using government power to supply public goods is that it is paternalistic: 'compelling us to contribute is paternalistic insofar as it does something for each of us that is good for us but that we cannot do for ourselves because we lack the collective will'. He goes on to say that '[t]his paternalism is benign in the sense that the end it helps us attain is not only good for us but is also an end we actually desire' (Schmidtz, 1991: 2). Although I agree that paternalism is a real worry, Schmidtz uses the term 'paternalism' in a way that I think we should reject. Gerald Dworkin suggests instead that for compulsion to count as paternalistic, it must override our judgment about purely self-regarding conduct (Dworkin, 1972). On Dworkin's influential account (in contrast to Schmidtz), if each of us recognizes an end as beneficial, but we lack the power to bring it about without the force of law, a law that compels us to do our part to achieve the end is not paternalistic since it does not override our judgment. Moreover, even when some people do not consider the coercive provision of a particular public good beneficial, if the reason for government provision is to prevent people from harming others, coercion is not paternalistic (whether any particular use of coercion is objectionable for other reasons is a separate question). For example, if the Center for Disease Control advocates a policy that requires most people to get vaccinated against smallpox, this is not paternalistic if the reason for requiring vaccination is to prevent people from spreading the smallpox virus to others. ${ }^{22}$

Paternalism aside, we might worry that if policy makers believe the theory that some public goods should be publicly provided because people would endorse their provision if they were adequately informed, they might be tempted to use this rationale to defend morally objectionable policies by appealing to the counterfactual desires of their constituents. While it is true that policy makers can misuse arguments, this does not show that the theory from which their arguments are drawn is false. For example, Henry Sidgwick famously argued that utilitarianism may be self-effacing (which implies that nobody should use it as a decision procedure) without being self-undermining (which implies that it is false). According to Sidgwick,

a Utilitarian may reasonably desire, on Utilitarian principles, that some of his conclusions should be rejected by mankind generally; or even that the vulgar should keep aloof from his system as a whole, in so far as the inevitable indefiniteness and complexity of its calculations render it likely to lead to bad results in their hands (Sidgwick, 1874: 490). 
The worry I want to raise is a natural extension of Sidgwick's. If policy makers tend to misuse arguments to justify policies that are not consistent with the arguments they appeal to, it may be desirable that they stop appealing to such arguments.

While it is conceivable that we would be better off if the theory of public goods had never been invented, or never been propagated to policy makers, this seems overly pessimistic. It is always possible for policy makers to appeal to arguments and principles that are either self-serving or unintentionally harmful. But this gives us a reason to constrain their discretionary power and pay attention to political incentives, not a reason to change our view about the complex connection between desire satisfaction, welfare, and public goods.

\section{Conclusion}

I have argued that although public goods are sources of market failure, and that governments can sometimes intervene to improve the outcome, widespread demand for public goods is, at best, a necessary condition for government intervention. There is no automatic link between demand and welfare, and the link is especially tenuous in the case of public goods because people have less incentive to become informed about goods which they lack the power to unilaterally produce or consume. In markets, poorly formed preferences are punished because buyers bear the costs of bad choices. In the political realm, this is rarely true since individual citizens have little power to decide through consumption or voting which public goods will be provided. This suggests that before policy makers decide to address a public goods problem with the machinery of government, they should consider whether demand for public goods stems from wellformed desires, whether the costs of public provision exceed the benefits, and whether markets will, all things considered, produce a better or worse outcome than government action.

\section{Acknowledgements}

Thanks to Geoffrey Brennan, Jerry Gaus, and Michael Munger for comments and conversations about these ideas.

\section{Funding}

This research received no specific grant from any funding agency in the public, commercial, or not-for-profit sectors.

\section{Notes}

1. Nonrivalry in consumption means that one person's consumption doesn't change the amount available for others to consume; nonexcludability means that nobody can be excluded from enjoying the good once its available. Many apparent public goods are easily provided by creating exclusion mechanisms (thus converting them into club goods) or by charging people as they use more of a good.

2. Head (1962) argues that the inability to separate public goods into discrete units with prices creates the main provision problem. 
3. James Buchanan explains it as follows:

The individual, as a member of a large group characterized by general interdependence among all of its members, will not expect to influence the behavior of other individuals through his own actions. He will not behave strategically; he will not bargain; he will not 'game.' Instead, he will simply adjust his own behavior to the behavior of others, taken as a composite unit... He accepts the totality of others' action as a parameter for his own decisions, as a part of the environment, a part of nature, so to speak... The small number case provides the individual with motivation both to initiate trade and to bargain over terms. The effective large number case ... tends to eliminate both trading and bargaining behavior' (1999: 82).

4. Scholars who explore how public goods can be supplied through non-governmental means (Ostrom, 1990) usually focus on local public goods with some degree of rivalry or excludability. Indeed, when cultural norms emerge among a small community of people, and norm violators are penalized - usually in the form of social stigma (in mild cases) or expulsion (in serious cases) - members of the community can transform public goods into private goods by excluding rule breakers from a variety of social benefits to which rule followers have access. In these cases cultural norms essentially serve the same function as enforceable property rights in large, liberal societies. Although adhering to norms and punishing norm violators is itself a public goods problem in the absence of state institutions, natural selection seems to have partly solved the problem by equipping most of us with moral emotions like shame and indignation, along with a powerful desire to punish those who undermine mutually-beneficial social norms (Gintis and Bowles, 2008; Ostrom, 2000).

5. For this reason, it can be misleading to describe public goods in terms of benefits that are nonrival and non-excludable. Technically, a good can be public even if it benefits nobody at all. The essential feature of public goods is that they must be available to everyone (and in equal amounts) if they are available to anyone. Thus, some public goods - even pure public goodsmay not be desired by anybody, and may be despised by nearly everybody. For example, a museum in Tel Aviv that glamorizes Nazism, but which doesn't charge admission fees, is a public good in the technical sense, but one for which there is little demand.

6. Mancur Olson's (1965) influential treatment of public goods problems as prisoners' dilemmas must be modified. First, since almost no public good is pure, we cannot represent all rational players as choosing a Pareto-dominated Nash equilibrium, as they would if the game were a true prisoner's dilemma. Second, while public goods are defined by generic features-nonrivalry and nonexcludability - prisoners' dilemmas, like all games, are defined by the preferences over outcomes of the particular people playing the game. If players are relatively altruistic, for example, the Pareto optimal action may be identical with the Nash equilibrium, in which case it's not a prisoner's dilemma. If the utilities in a game reflect everything the players care about, and some players care how an outcome is reached, or about the other people with whom they are playing, they may be modeled by a different game than other players in the same situation with different motivations.

7. Some take this to show that we should rely more on expert opinion than on citizens' sentiments on complex issues that require a high degree of scientific competence. Others take it to suggest skepticism about empowering experts who will also be subject to bias if not ignorance. 
8. For more on the scandal, see Paul Offit (2010). For more on the moral significance of the controversy, see Tom Sorrel (2007).

9. Other recent cases that are structurally similar include unfounded skepticism among many Americans about the connection between carbon emissions and climate change, and an unfounded belief among many Europeans that genetically modified foods cause various medical disorders.

10. Preferences differ from desires only in the sense that preferences are rankings over alternative bundles of goods or states of affairs, while desires can be aimed at a single good or state of affairs.

11. See especially Richard Brandt (1979), David Gauthier (1986: ch. 2), and Hausman and McPherson (2006: ch. 8) for attempts to distinguish which satisfied preferences should count as welfare-enhancing rather than welfare-diminishing.

12. See Parfit (1984: ch. 6).

13. This criterion is admittedly vague. But, as Aristotle reminds us, we shouldn't expect more precision than a subject matter admits of:

We must be content in speaking of such subjects and with such premises to indicate the truth roughly and in outline, and in speaking about things which are only for the most part true and with premises of the same kind to reach conclusions that are no better. In the same spirit, therefore, should each type of statement be received; for it is the mark of an educated man to look for precision in each class of things just so far as the nature of the subject admits ( 350 BCE, Bk 1, Section 3).

14. Stiglitz (1999).

15. This is a clear case in which the dichotomy between market versus government or public versus private provision is artificially stark. Much basic science research is funded by state governments, but distributed to private, public, and non-profit institutions - including firms and universities - on a competitive basis.

16. Mill and Sidgwick also anticipated arguments that (what we now call) market failures should always be compared with governmental policies that might make the problem worse, given the incentive and information problems faced by bureaucrats. See Steven Medema (2007).

17. See Harold Demsetz (1993: 564).

18. Although I am tempted to distinguish between public production and public provision of public goods, since most authors who write about public goods equate 'provision' and 'production', I will stick with direct versus indirect provision, and use 'provision' and 'production' interchangeably.

19. Insurance mandates can also be a way for legislators to redistribute risk and wealth without the state getting directly involved in taxing and spending. More cynically, they are sometimes simply a legally-sanctioned transfer of wealth from citizens to insurance companies. I do not take a stand on whether insurance mandates are justified, or whether the argument from risk sharing or adverse selection is plausible.

20. Although some use 'coercion' to refer to the use or threat of force by one party against another in such a way that the coerced party's rights are violated, I use 'coercion' in a morally neutral way. 'Coercion' does imply that the coerced party's viable options are diminished (due in part to a fear of punishment), but it does not imply that his rights are violated or that his welfare is 
reduced. Indeed, Hobbes argues that coercively enforced laws can promote welfare by increasing trust, coordination, and exchange (Hobbes, 1651: ch. 15).

21. For example, most people have never heard of the Montreal Protocol on ozone depletion, and among those who have, many believe that climate change and ozone depletion are the same problem. According to a recent survey on American attitudes about climate change,

large majorities incorrectly think that the hole in the ozone layer and aerosol spray cans contribute to global warming, leading many to incorrectly believe that banning aerosol spray cans or stopping rockets from punching holes in the ozone layer are viable solutions (Leiserowitz et al., 2010: 4).

22. Public goods that are justified not as mechanisms to prevent people from harming others, but rather as a way of promoting a preference we would have if better informed would count as paternalistic on Dworkin's view, and potentially as justified paternalism.

\section{References}

Anomaly J (2012) Is obesity a public health problem? Public Health Ethics 5(3): 216-221.

Aristotle (350 BCE) Nichomachean Ethics. Available at: http://classics.mit.edu/Aristotle/nicomachaen.html (accessed 9 January 2013).

Barendregt J, Bonneux L and van der Mass P (1997) The health care costs of smoking. New England Journal of Medicine 337: 1052-1057.

Brandt R (1979) A Theory of the Good and the Right. Oxford, UK: Clarendon Press.

Buchanan J (1993) How can constitutions be designed so that politicians who seek to serve the public interest can survive and prosper? Constitutional Political Economy 4(1): 1-6.

Buchanan J (1999) The demand and supply of public goods. In: The Collected Works of James M. Buchanan. Indianapolis, IN: Liberty Fund. First published 1968.

Buchanan J and Brennan G (1999) The reason of rules: constitutional political economy. Indianapolis, IN: Liberty Fund. First published 1985.

Buchanan J and Tullock G (1962) The Calculus of Consent. Ann Arbor, MI: University of Michigan Press.

Caplan B (2008) The Myth of the Rational Voter. Princeton, NJ: Princeton University Press.

Coase R (1960) The problem of social cost. The Journal of Law and Economics 3: 1-44.

Cornes R and Sandler T (1996) The theory of externalities, public goods, and club goods. Cambridge, UK: Cambridge University Press.

Cowen T (2006) Good and Plenty. Princeton, NJ: Princeton University Press..

Demsetz H (1993) The private production of public goods, once again. Critical Review 7(4): $559-566$.

Diamond P and Hausman J (1994) Contingent valuation: Is some number better than no number? Journal of Economic Perspectives 8(4): 45-64.

Diamond P, Hausman J, Leonard GK, et al. (1993) Does contingent valuation measure preferences? Experimental evidence. In: Jerry Hausman (ed.) Contingent Valuation: A Critical Assessment. Amsterdam: North Holland Press.

Downs A (1957) An economic theory of political action in a democracy. The Journal of Political Economy 65(2): 135-160.

Dworkin G (1972) Paternalism. The Monist 56: 64-84. 
Gaus G (2007) On Philosophy, Politics and Economics. Belmont, CA: Thomson Wadsworth. Gauthier D (1986) Morals by Agreement. Oxford, UK: Oxford University Press.

Gintis H and Bowles S (2008) The evolutionary basis of collective action. In: The Oxford Handbook of Political Economy. Oxford, UK: Oxford University Press.

Hampton J (1986) Hobbes and the Social Contract Tradition. Cambridge, UK: Cambridge University Press.

Hampton J (1987) Free rider problems in the production of collective goods. Economics and Philosophy 3: 245-273.

Hausman D and McPherson M (2006) Economic Analysis, Moral Philosophy and Public Policy, 2nd ed. Cambridge, UK: Cambridge University Press.

Hayek F (1945) The use of knowledge in society. American Economic Review 35(4): 519-530.

Head JG (1962) Public goods and public policy. Public Finance 17(3): 197-219.

Hobbes T (1651) Leviathan. Available at: http://oll.libertyfund.org/?option=com_staticxt\&static file $=$ show.php $\% 3$ Ftitle $=869$ (accessed 9 January 2013).

Holcombe R (2000) Public goods theory and public policy. The Journal of Value Inquiry 34: 273-286.

Huemer M (forthcoming) Why people are irrational about politics. Available at: http://home.spry net.com/ owl1/irrationality.htm (accessed 9 January 2013).

Hume D (1739) A Treatise of Human Nature. Available at: http://oll.libertyfund.org/index.php? option $=$ com_staticxt\&staticfile $=$ show.php\%3Ftitle $=342 \&$ Itemid $=27 \#$ toc_list $\quad$ (accessed 9 January 2013).

Kavka G (1986) Hobbesian Moral and Political Theory. Princeton, NJ: Princeton University Press. Kelman S (1981) Cost-benefit analysis: An ethical critique. Regulation 5: 33-40.

Leiserowitz A, Smith N and Marlon JR (2010) Americans' Knowledge of Climate Change. New Haven, CT: Yale Project on Climate Change Communication. Available at: http://environment. yale.edu/climate/files/ClimateChangeKnowledge2010.pdf (accessed 9 January 2013).

Medema S (2007) The hesitant hand: Mill, Sidgwick and the evolution of the theory of market failure. History of Political Economy 39(3): 331-358.

Offit P (2010) Autism's False Prophets. New York, NY: Columbia University Press.

Olson M (1965) The Logic of Collective Action. Cambridge, MA: Harvard University Press.

Ostrom E (1990) Governing the Commons: The Evolution of Institutions for Collective Action. Cambridge, UK: Cambridge University Press.

Ostrom E (2000) Collective action and the evolution of social norms. Journal of Economic Perspectives 14(3): 137-158.

Parfit D (1984) Reasons and Persons. Oxford, UK: Oxford University Press.

Pigou AC (1932) The Economics of Welfare, 4th ed. London, UK: Macmillan Press.

Rawls J (1971) A Theory of Justice. Cambridge, MA: Harvard University Press.

Samples K and Hollyer J (1990) Contingent Valuation of Wildlife Resources in the Presence of Substitutes and Complements. Boulder, CO: Westview Press.

Samuelson P (1954) The pure theory of public expenditure. The Review of Economics and Statistics 37(4): 350-356.

Samuelson P (1972) Indeterminacy of government role in public-good theory. In: RC Merton (ed.) The Collected Scientific Papers of Paul A. Samuelson, volume 3. Cambridge, MA: MIT Press.

Schmidtz D (1987) Contracts and public goods. Harvard Journal of Law and Public Policy 10: 475-503. 
Schmidtz D (1991) The Limits of Government: An Essay on the Public Goods Argument. Boulder, CO: Westview Press.

Schmidtz D (1993) Market failure. Critical Review 7(4): 525-537.

Schmidtz D (2001) A place for cost-benefit analysis. Philosophical Issues 35: 148-170.

Sidgwick H (1981) The Methods of Ethics, 7th ed. Indianapolis, IN: Hackett Publishing. First published 1874.

Smith A (1776) An Inquiry into the Nature and Causes of the Wealth of Nations. Available at: Econlib.org/library/smithsmWN.html (accessed 9 January 2013).

Sorrel T (2007) Parental knowledge and expert choice in the debate about MMR and autism. In: Ethics, Prevention and Public Health. Oxford, UK: Oxford University Press.

Stiglitz J (1999) Knowledge as a global public good. In: Inge Kaul (ed.) Global Public Goods. Oxford, UK: Oxford University Press.

Sugden R (1990) Rules for choosing among public goods: A contractarian approach. Constitutional Political Economy 1(2): 63-82.

Tolley G, Randall A, Blomquist G, et al. (1983) Establishing and valuing the effects of improved visibility in the Eastern United States. Report to the US Environmental Protection Agency, Washington, DC.

Tullock G (1971) Public decisions as public goods. Journal of Political Economy 79(4): 913-918. van Ball P, Polder J, de Wit G, et al. (2008) Lifetime medical costs of obesity. PLoS Medicine 5: 242-249.

Varian H (1993) Markets for public goods? Critical Review 7(4): 539-557.

\section{Author biography}

Jonathan Anomaly is a core faculty member in the Duke/UNC program in philosophy, politics and economics. 